\title{
Exploring the Drivers and the Interventions towards Sustainable Food Security in the Food Supply Chain
}

\author{
Hao Yuan Chan ${ }^{1}$, Sarina Abdul Halim-Lim ${ }^{1, *}$, Tai Boon Tan ${ }^{2}$, Nitty Hirawaty Kamarulzaman ${ }^{3}$, \\ Adi Ainurzaman Jamaludin ${ }^{4}()^{-}$and Wan Abd Al Qadr Imad Wan-Mohtar ${ }^{5}$ \\ 1 Department of Food Technology, Faculty of Food Science and Technology, Universiti Putra Malaysia, \\ Serdang 43400, Malaysia; samuel.tfa@gmail.com \\ 2 Department of Food Service and Management, Faculty of Food Science and Technology, \\ Universiti Putra Malaysia, Serdang 43400, Malaysia; taiboontan@upm.edu.my \\ 3 Department of Agribusiness and Bioresource Economics, Faculty of Agriculture, Universiti Putra Malaysia, \\ Serdang 43400, Malaysia; nitty@upm.edu.my \\ 4 Environmental Science and Management Programme, Institute of Biological Sciences, Faculty of Science, \\ Universiti Malaya, Kuala Lumpur 50603, Malaysia; adiainurzaman@um.edu.my \\ 5 Functional Omics and Bioprocess Development Laboratory, Institute of Biological Sciences, \\ Faculty of Science, Universiti Malaya, Kuala Lumpur 50603, Malaysia; qadyr@um.edu.my \\ * Correspondence: sarinalim@upm.edu.my
}

Received: 22 August 2020; Accepted: 16 September 2020; Published: 24 September 2020

\begin{abstract}
The sustainability of food security is a global concern, and one of the priorities related to it is the ability to identify effective efforts that can protect food security along the food supply chain (FSC). The present study demystifies the relation of sustainability and food security and structurally identifies the sustainable drivers, and the pragmatic interventions that can critically contribute to the sustainability of food security within each stage of the FSC. A systematic review of articles from six databases was implemented. Thematic analysis was engaged to detect the sustainable drivers and interventions practised at each stage in the FSC for food security purposes. Six main themes of the drivers and interventions were derived from the analysis: food security governance involvement, input resource management, output management, information sharing, income, and technology. The result identifies the potential that quality management has on the mediating effect towards sustainable food security, through which a conceptual model for sustainable food security in the FSC was thus developed. It is deduced that mapping and categorizing the drivers and intervention of sustainable food securities could help deepen the understanding of effective and innovative practices towards food security in the FSC.
\end{abstract}

Keywords: food security; sustainability; food supply chain; quality management; drivers; interventions

\section{Introduction}

Global intention to fight hunger and malnutrition at the outset of the food security concept was first introduced in the World Food Conference in 1974. However, at that point in time, the idea was substantially focused on the national and international level, to secure the stability of basic food stock prices [1]. The development of the food security concept then moved its focal point to the individual level when the Food and Agriculture Organization (FAO) alerted the importance of equal food availability in 1983. After that, the concept took more enormous strides, with the official declaration of the World Food Security concept in the Rome Declaration on World Food Security in 1996 [2]. Subsequent development during the 2009 World Summit on Food Security has led to the recognition of "four pillars" of food security, namely: stability, availability, accessibility, and utilization [3-5] 
Conventionally, food security embodies the person-focused concept. Nevertheless, further discussion has discerned that the sustainability concept is very relevant to food security [6].

The concept of sustainability had a stake on the international round table in 1974 when the World Commission on Environment and Development precisely defined it as the continual development of the international economy that meets present needs. Under any circumstances, sustainability should not compromise future generations' ability to meet their own needs. Since then, there has been intense debate among experts in addressing the drawback of sustainability concepts, which had focused mainly on economics [6]. Later, the triple bottom line (TBL) encompassing economic prosperity, environmental quality, and social justice concepts, was introduced. This helped to shed light on the controversy of sustainability concept viewed previously [7]. Merchants are aware that a product's quality uptrend is expected to focus on the economical, ecological, and social impact, which in turn are associated with the products' lifecycle. As a result, the concept of sustainability has become the centre of attention in products and services in the supply chain, across various industries. This is in stark contrast with convention food security that only focuses on food agendas [8].

In its State of Food Security and Nutrition in the World report, the FAO recognized that the major drivers of food security include economic downturn, climate vulnerability, and conflicts [9-11]. It then recommended several approaches that food security governance can adopt for the development of food security. The report indicated that these drivers showed a close resemblance to the sustainable development drivers. This means that sustainability is a participatory concept of food security and that food security synergy is linked to sustainable drivers [7,12]. A considerable number of existing studies have discussed the potential synergy and the development trend of sustainability concepts in the food security notion $[4-6,13]$.

Concerning sustainable food security drivers, about $64 \%$ of the published articles relating to food security governance addressed food security at the global level, i.e., in FAO, the Committee on World Food Security, the G20, and national government centre [14]. The private sector has a significant role in food security in the food supply chain (FSC), but their contributions in the body of knowledge are still comparatively vague. Previous studies only focused on drivers, such as greenhouse gas (GHG) emissions and food waste generation $[15,16]$. No extensive review on other drivers; moreover, there is a lack of systematical analysis of the type of interventions in the context of sustainable development being used in the FSC for the betterment of food security $[15,16]$. There is limited knowledge about variations across value chains, information that would improve overall target (value chain)-based interventions and strategies. Therefore, this study aims to address the gap and answer the key question: "What are the sustainable drivers that match the food security and pragmatic interventions (practical activities, events, or actions that entail effect) being implemented at each sector of the FSC that could lead to the betterment of food security?"

\section{Materials and Methods}

Systematic literature review (SLR) is an approach of making sense of large bodies of information in a systematic way to provide convincing evidence to address some compelling issues. It is also a way of mapping out areas of uncertainty, and a way of identifying areas with little or no research done to detect if new input or research is required [17]. The SLR approach engaged in this study was adapted from previous scholars, such as Mohamed Shaffril et al. [18], Halim Lim et al. [19], and Tranfield et al. [20]. The SLR approach used in this study encompasses three main stages: (i) resource searching, (ii) review processing, and (iii) data abstraction and analysis.

\subsection{Resource Searching}

The approach of the SLR is characterized as a systematic review of literature that is inexhaustive in nature, but this approach focuses on the usage of multiple databases because it is crucial to increase the tendency of attaining articles in the targeted topic to avoid the risk of missing any critical materials [21]. This study utilized several databases to locate the resources needed for this review. Scopus served as the 
main database, in accompaniment with other slightly smaller resources, such as Science Direct $(\mathrm{n}=32)$, Wiley Online Library $(n=50)$, Emerald $(n=40)$, Springer $(n=10)$, and SAGE $(n=45)$. Scopus was chosen because it is one of the leading databases, with more than 75 million records, including 24,600 active titles and 5000 publishers. The other databases were also beneficial in other ways; for instance, Science Direct is one of the leading platforms for peer-reviewed literature. It has more than 2500 technical, health, and scientific journals, spanning 24 major scientific disciplines. The Recommendation featured in Science Direct also provides more efficient snowballing search for articles by suggesting relevant articles based on current reading.

\subsection{Systematic Review Process}

\subsubsection{Tracking and Retrieve}

Systematic review process encompasses tracking the right articles, and this step began with the development of keywords that had been suggested by the authors. These were based on similar contexts and terms, and then adopted for the search [6,12,22-24]. For the current study, the search string was developed in September 2019 to locate the relevant articles in Scopus. An extremely large volume of articles (4950 document results) was located by using the TITLE-ABS-KEY ("food security" OR "food insecurit*" AND "sustainab*" OR "sustainab* development"), AND TITLE-ABS-KEY ("agricultur*" OR "manufactur" OR "producer" OR "retail" OR "restaurant" OR "logistic" OR “delivery" OR "supply chain" OR "value chain"). However, due to the consequence of tracking bias and variance, a large population of the articles located also included irrelevant articles. To eliminate these redundancies, the search string was readjusted to TITLE ("food security" OR "food insecurit" AND "sustainab" OR "sustainab* development) AND TITLE-ABS-KEY ("agricultur*" OR "manufactur*" OR "producer" OR "retail" OR "restaurant" OR "logistic" OR "delivery" OR "supply chain" OR "value chain"). Consequently, a total of 229 articles were successfully identified in Scopus. Manual searching was also performed using similar keywords on other databases. This resulted in another 177 articles. Thus, in total, there were 405 articles that were successfully retrieved.

\subsubsection{Screening}

The identified articles $(n=405)$ were then screened based on inclusion and exclusion criteria, as illustrated in Table 1. Only articles with primary data and explicit discussion of relationship, drivers, and intervention between food security and sustainable system under the FSC were accepted. Articles from agriculture, manufacturing, logistics, retail, and restaurants were included in the review process, but only those from peer-reviewed sources were selected. Others, like literature review, book chapters, and articles from conference proceedings, were excluded so as to ensure the quality of the articles selected. Only English articles published between 2009 to 2019 were selected to reflect a decade of publication on the issue and to avoid the possibility of translation error variance and obsolete information. The screening process resulted in the exclusion of 341 journal articles, and 64 articles identified as relevant for review.

\subsubsection{Eligibility}

The primary purpose of the eligibility step was to identify further the articles which contain the intended information that can answer the research question and to exclude those that do not. The eligibility process is illustrated according to PRISMA 2009 (Figure 1). Sixty-four articles were further screened for eligibility through the title, abstract, and main contents. A further exclusion was carried out for articles that do not contain explicit discussions of the relationship, drivers, and intervention between food security and sustainability under the context of the food supply chain, and also articles without primary data. Consequently, 24 articles were excluded, leaving only 40 eligible articles to be used for further analysis. 
Table 1. Inclusion and exclusion criteria to assess and organize articles.

\begin{tabular}{|c|c|c|c|}
\hline Criterion & Inclusion & Exclusion & Justification \\
\hline Context & $\begin{array}{l}\text { Food supply chain (FSC)/value } \\
\text { chain including manufacturer, } \\
\text { logistic, retail, and restaurant }\end{array}$ & $\begin{array}{l}\text { Other than food supply chain } \\
\text { Experimental } \\
\text { Laboratory }\end{array}$ & $\begin{array}{l}\text { Only include articles with explicit discussion on } \\
\text { sustainable food security in the context of the FSC } \\
\text { that could answer the research question. }\end{array}$ \\
\hline Intervention & $\begin{array}{l}\text { Food security } \\
\text { Sustainability }\end{array}$ & $\begin{array}{l}\text { Environment (laboratory) } \\
\text { Scientific experimentation }\end{array}$ & $\begin{array}{l}\text { Only articles with primary data and explicit } \\
\text { discussion on sustainable practices towards food } \\
\text { security state. }\end{array}$ \\
\hline Mechanism & Implementation & $\begin{array}{c}\text { Readiness } \\
\text { Barriers } \\
\text { Scientific experimentations }\end{array}$ & \\
\hline Output & $\begin{array}{c}\text { Drivers } \\
\text { Pragmatist intervention } \\
\text { Relationship } \\
\text { Quality management }\end{array}$ & & $\begin{array}{l}\text { Articles with primary data and explicit discussion } \\
\text { on relationship between sustainability and food } \\
\text { security, drivers, and intervention between food } \\
\text { security and sustainable system under food } \\
\text { supply/value chain, i.e., agriculture, } \\
\text { manufacturing, logistic, retail, and restaurant. }\end{array}$ \\
\hline $\begin{array}{l}\text { Literature } \\
\text { type }\end{array}$ & Journal (research articles) & $\begin{array}{l}\text { Any articles without primary } \\
\text { data, for example, but not } \\
\text { limited to literature review, } \\
\text { book chapter, conference } \\
\text { proceedings }\end{array}$ & $\begin{array}{l}\text { Only include articles with primary data to avoid } \\
\text { synthesis error variance in secondary sources. }\end{array}$ \\
\hline Language & English & Other than English & To avoid translation error variance. \\
\hline Timeline & 2009-2019 & $<2009$ & $\begin{array}{l}\text { To review latest development (in the last decade) in } \\
\text { food security and sustainable system. }\end{array}$ \\
\hline
\end{tabular}

\subsection{Data Analysis}

Using the thematic analysis, this study synthesized the sustainable drivers together with the pragmatic interventions that affect the state of food security. The term drivers in this study refers to the factors that directly or indirectly influence the food security state $[25,26]$, while pragmatic interventions refer to any practices that directly or indirectly influence the food security states [27,28]. First, a database was established to collect, extract, store, and categorize the information for descriptive analysis. Next, the articles were analyzed based on categories which include publication year, research country (if not specified, then primary author's country of origin), application sectors (i.e., agriculture, manufacturing, logistics, retail and restaurant, supply chain), research approach, and designs [12]. Following this, thematic analysis was performed by extracting the statements or data that helped to answer the research question. Subsequently, the comments were grouped into relevant themes which then led to the creation of concepts or ideas [29].

Main themes and subthemes were developed for each category so as to collect the relevant information of the sustainability drivers and pragmatic interventions. For instance, an article statement that elicited the effect of agricultural yield on food security state would be grouped under the sustainable drivers of the "output management" theme, and the subtheme of "yield", alongside the type of pragmatic interventions that facilitate the drivers. Each theme's definition was standardized among the authors. ISO 9000: 2015 was used for the theme definition and the food security governance definition was adopted from Termeer et al. [30]. The formal and informal interactions across scales between public and/or private entities were ultimately aiming at the realization of food availability, food access, and food utilization, and their stability over time.

Next, the data analysis process through thematic analysis began with a set of a priori codes; however, the codes were flexible as the analysis progressed [31]. The drivers were cross-referenced to related sustainable domains and food security pillars [6,32]. The codes were then stored and defined in a codebook and compared with the terms used in the key articles to address any inconsistency that occurred during the process of theme development. Consultations and consensus among the authors were acquired for the agreement of the themes to minimize cognitive bias [31]. 

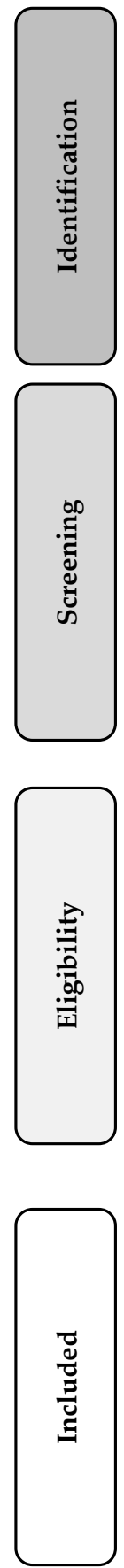

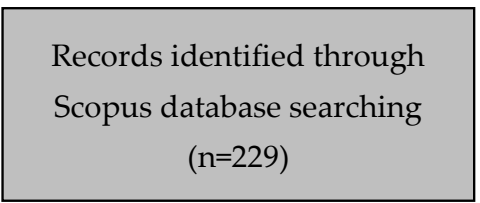

Additional records identified through other sources - Science Direct ( $\mathrm{n}=32)$, Wiley Online Library ( $\mathrm{n}=50)$, Emerald $(n=40)$, Springer $(n=10)$, SAGE $(n=45)$

Records after duplicates removed $(\mathrm{n}=405)$
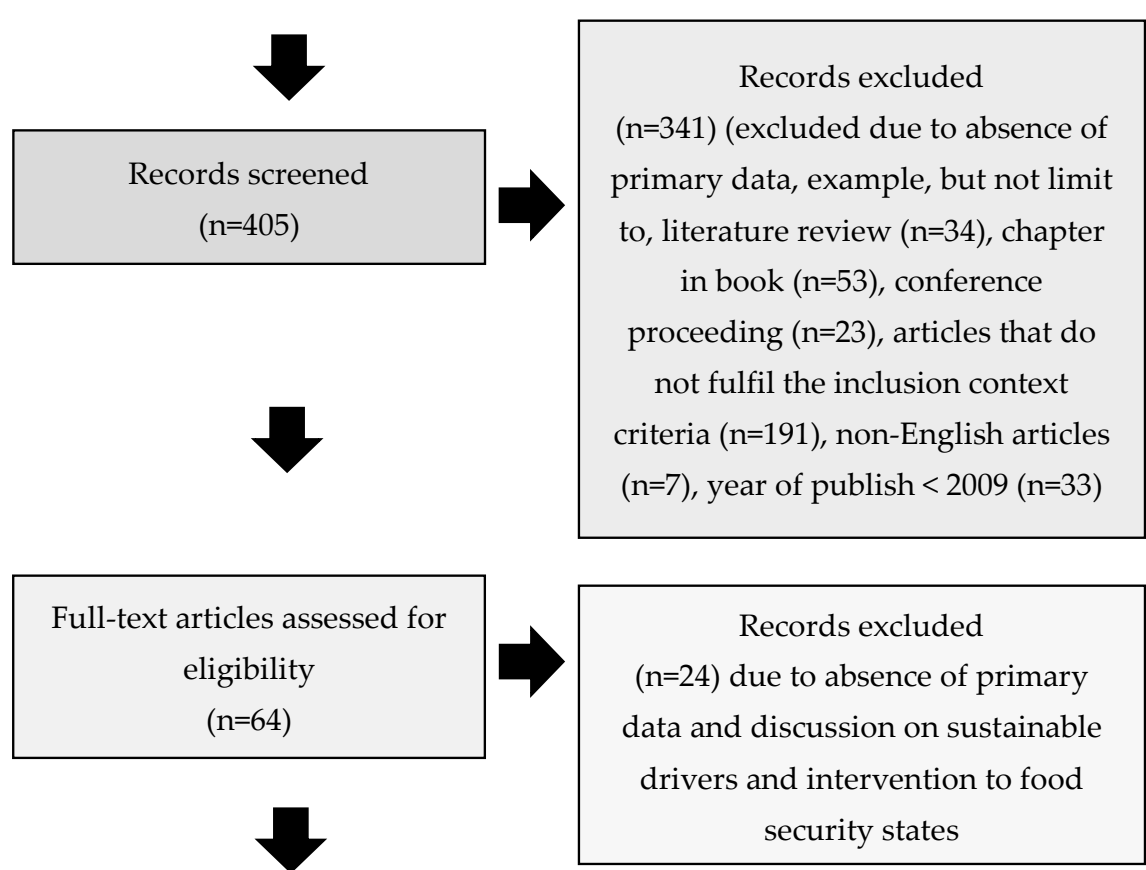

Studies included in qualitative synthesis $(\mathrm{n}=40)$

Figure 1. Systematic review-process flow figure (PRISMA).

\section{Results}

\subsection{Trends of the Publications}

The frequency distribution of the articles, according to the sectors in the FSC, is illustrated in Figure 2. It was observed that $43 \%$ of the articles focused on agriculture agendas. This sector certainly evoked the interests of researchers in the sustainable food security system. Next in line were $23 \%$ of the articles that comprise research in the manufacturing industry sector, while discussion on retail and logistics lagged far behind with $5 \%$ and $8 \%$, respectively. 


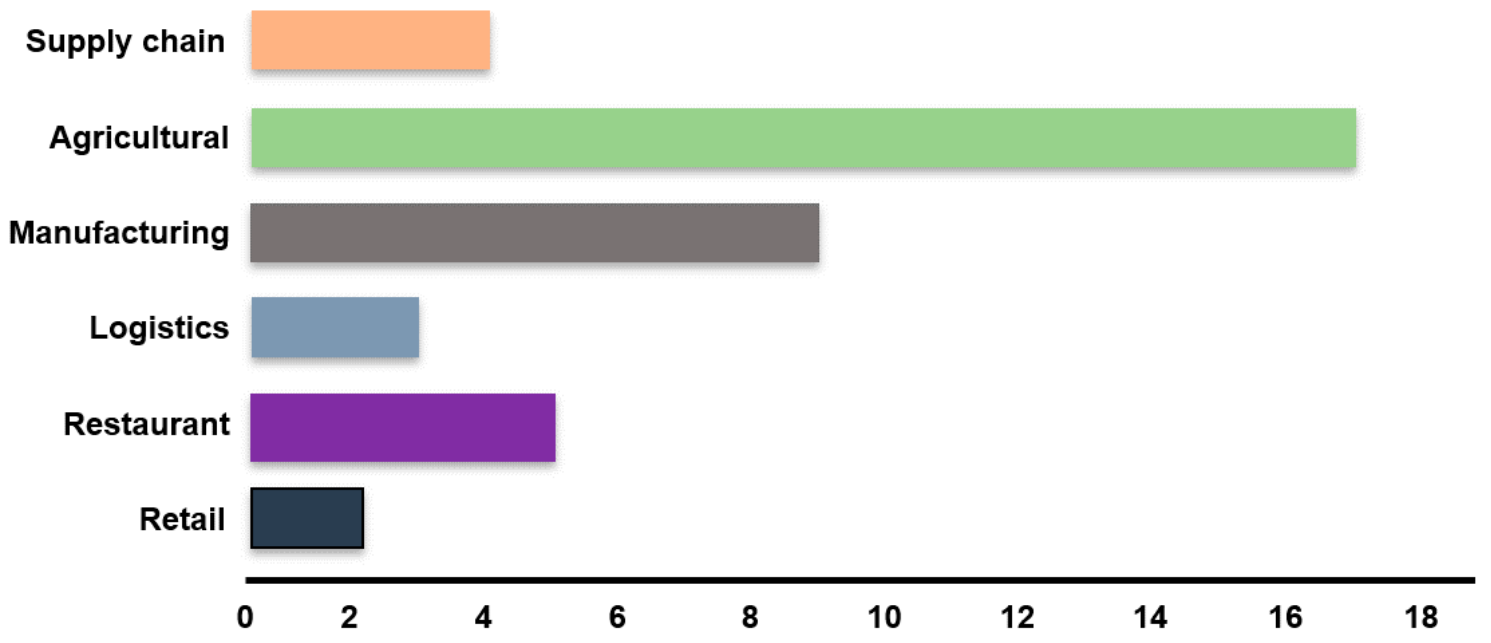

Figure 2. The distribution of articles according to the FSC sector.

The year of publication frequency is illustrated in a Pareto chart (Figure 3). The $y$-axis on the left represents the number of papers published. The bar chart is arranged in the order of the highest number of articles to the lowest number of articles, based on the Pareto chart principle. The right-axis and the line represent the cumulative percentage of the published articles, whereas the $x$-axis represents the year that the articles were published. The line chart is a visual subtool used to depict cumulative percentage to directly spot whether a certain set of data follows the $80 / 20$ rule, moving from left to right across the analysis, to a total of $100 \%$. It was observed that $80 \%$ of the articles were published only in recent years (between 2015 to 2019). Thus, it suffices to say that the broach on the sustainable food security system in the FSC is still in its infancy.

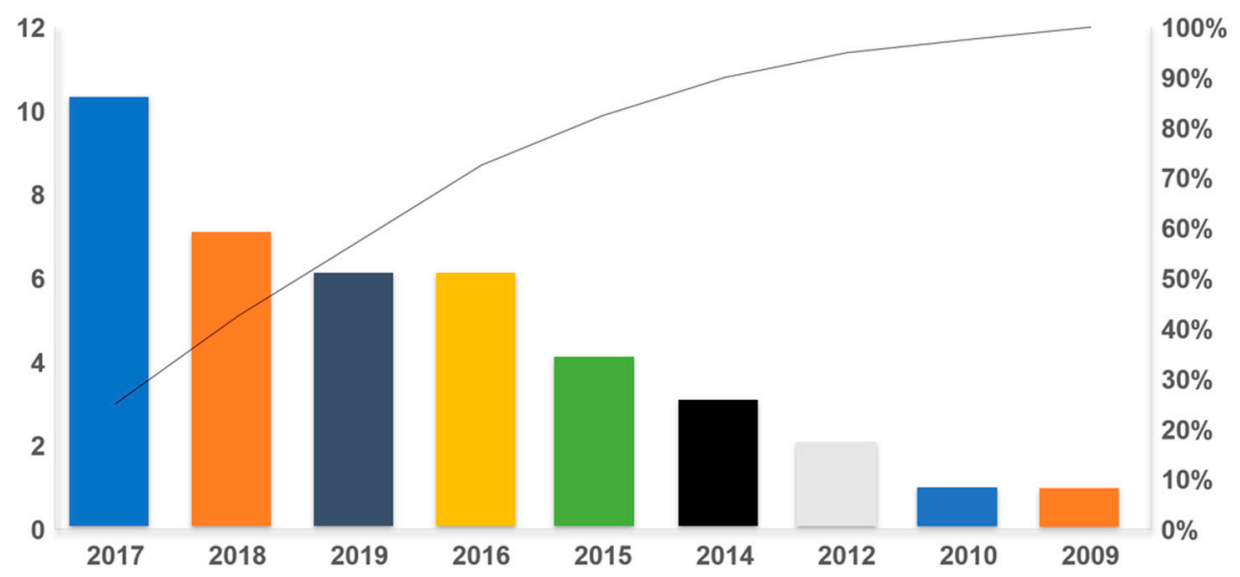

Figure 3. Pareto diagram of articles based on the year of publication.

Figure 4 depicts that the interest and proposition of sustainable food security within the FSC was distributed across the globe, including Asia, Europe, North and South America, and Africa. The highest number of our analyzed articles (23\%) come from the world's largest economic countries, like China and the United States of America. Nonetheless, the focus of the studies between these two leading countries was different. Studies from China focused primarily on agricultural agenda, whereas those from the United States of America prioritized on issues about sustainability on food manufacturing, restaurants, and FSC. It is relatively straightforward to envisage that China, as the most populous country in the world, has its focal point on sustainable agricultural agenda as the country itself has more than 1.4 billion people to feed daily. Its population is anticipated to grow continuously, year-by-year [33]. 


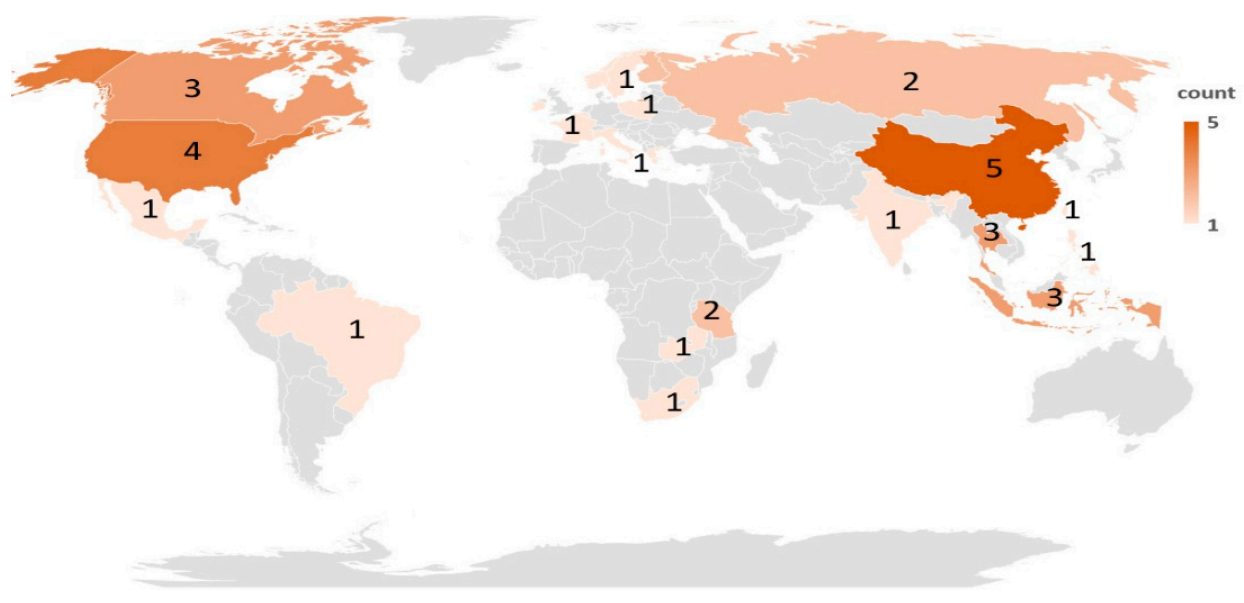

Figure 4. Geographical distribution of the studies.

Meanwhile, the United States of America's Global Food Security Strategy from 2017-2021 aimed at strengthening sustainable food security in the entire food and agriculture system. This may help to explain why the country was prioritizing issues of sustainability in food manufacturing, restaurants, and FSC [34].

Apart from the United States and China, the global commitments to resolve food insecurities and hunger are demonstrated through the participation of sustainable development resolution [35]. For instance, the African Development Bank (AfDB) actively promotes food chain sustainable developments by offering various funding options for African investors [36]. The European Commission has also striven to reduce $50 \%$ of food waste by the year 2025 by deploying various food security strategies and policies [37]. As importantly, the review of Mottet et al. [38] illustrated the challenges and strategies, including policies, regulations, research, and development of the sustainable domestic herbivore production in Latin America and South Asia.

From the research approach and design (Figure 5), 70\% of the studies used a quantitative approach, with quantitative survey appearing to be the dominant method used in the nonexperimental design, as compared to other research methods, since the food security state tends to stem from generalizing the individuals' experiences, household, national, regional, and global level [14]. Meanwhile, $15 \%$ of the studies implemented the qualitative approach, predominantly using the case study method. This is because the method allows an in-depth investigation into the implementation of the pragmatic interventions towards the betterment of food security states.

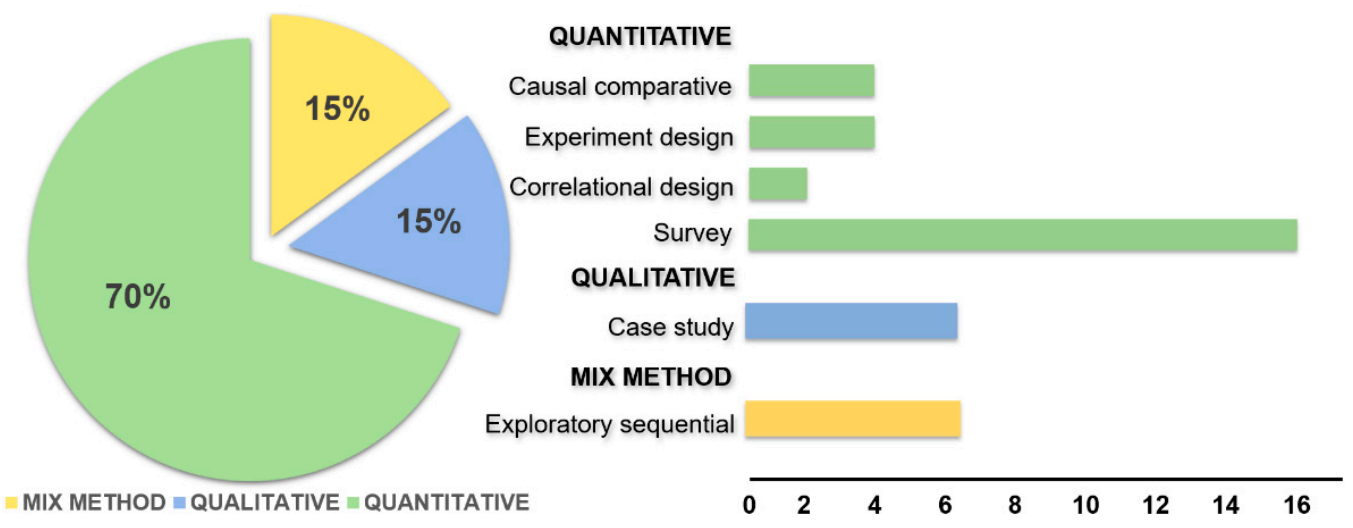

Figure 5. Research approach and design. 
The remaining $15 \%$ of the studies belonged to the mixed-method approach, largely based on exploratory sequential (quan-qual) method, with the primary intention to explore the individuals' perception and experiences of food security.

\subsection{The Domain of Sustainable Food Security}

The sustainable drivers that have relation with food security states were articulated by Schindler et al. [32], Hassini et al. [39], Petit et al. [40], and Kummu et al. [41]. The list consists of nine sustainability drivers that related to food security:

1. Balanced and diversified diet

2. Community support program

3. Employees' health, safety, and welfare

4. Agronomic education

5. Sufficient food

6. Fair income and freedom to trade

7. Soil fertility

8. Positive water supply for agricultural activities

9. Agrodiversity

The SLR shows that the "Sustainability" and "Supply Chain Sustainability" maturity models do not require a network perspective following the TBL approach [7]. Sustainability drivers were then mapped and categorized based on the food security and sustainability dimensions proposed by Schindler et al. [32], since they had concluded that the potential of food security in smallholder agrifood systems, and local foods, largely depended on the socioeconomic and environmental criteria.

Similarly, labor welfare, investment, and waste and loss rate related to the social domain; finished products' quality was related to the social and economic domain; costing (including labor and finance) was related to the economics domain; and finally, water, land, air usage, and toxicity were related to the environmental field of sustainability [40]. Nevertheless, the study does not further map the food security domain. Siddh et al. [42], based on grounded theory, showed that the internal quality of perishables had a positive impact on the social, economic, and environmental output of perishables in the FSC. In a study looking at the implications of food waste on sustainability development, Kummu et al. [41] concluded that food waste reduction was affected by economic, political, and social factors, and these would eventually improve the state of food security.

Figure 6 shows the categorization of the sustainability attributes derived from previous studies. These categorizations include employees' health, safety, and welfare [32], and labor welfare [40]. They were then grouped under the "health, safety, and welfare" category. Other categorizations include agrodiversity [32], finished product quality [40], and internal quality. They were grouped under the "product quality and diversity" category [42]. This visual effect ascribed the challenges of delineating each attribute to the respective triple bottom line domain. Nevertheless, every sustainable domain eventually contributed to the food security state.

\subsection{Sustainable Food Security Drivers and Pragmatic Interventions in the Agriculture Sector}

The literature indicated the most common driver of sustainable food security is the food security governance decisions [43-48], which subsidy and assistance programs are the most implemented interventions globally. The state of government policy, transformation programs, and subsidies, positively leaned towards attaining the "availability" domain in food security [47]. Nonetheless, such policies have obscured the environmental impact, resulting in a higher environmental cost per unit of rice output, but with approximately twice the level of fertilizer and pesticide input. It was recommended that the policy development should consider various scales of farm households and cropping patterns that were consistent with farmland grain-planting suitability. 


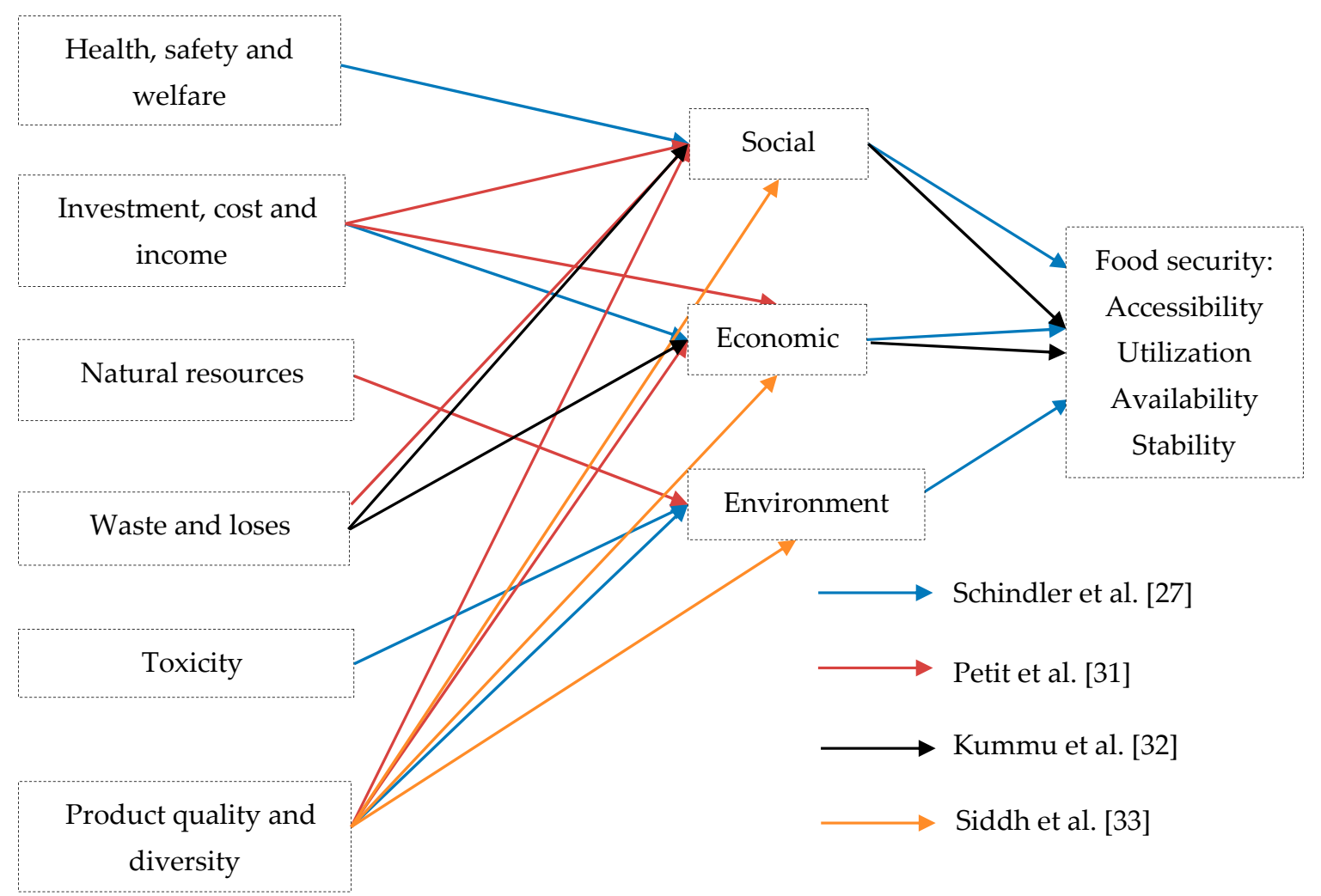

Figure 6. Mapping triple bottom line (sustainability) to the food security concept and its attributes.

Most of the interventions implemented in agriculture were meant to improve yield and to lower the environmental costs, with better economic gains across land and water [32,43,47,49-53]. Consequently, better resource efficiency with less costly input is in tandem with the market's participation. This caused the self-determination of prices to increase the net income of farmers and laborers, hence improving household food security states [32,54]. Salary, food prices, and accessibility to food markets all influence food purchases and should be considered as part of the food security drivers.

From the perspective of land usage, it was found to be equivalent to water and energy footprints $[32,51,55]$. The status of the tenure and ownership of the lands determined the fate of the land usage (households with customary land tenure had a $17.4 \%$ lower probability of adopting crop diversification). Crop diversification was observed to be an intervention that exhibited a strong impact on the household food security state [51]. Several interventions were implemented to improve water efficiency, including (i) terracing, (ii) area closure, (iii) planting fodder grasses, (iv) planting legumes and trees, (v) soil bund construction, (vi) crop rotation, (vii) stop free grazing, (viii) waterways, (ix) manure, (x) inorganic fertilizer, (xi) dams inspection, and (xii) cut off drains [32,45].

The household food security state was also greatly influenced by the farmers' and laborers' competency level $[32,45,50,54,56]$. The effort to systematically improve the farmers' technical knowledge (in labor technical productivity change) in the agricultural production process would contribute to the betterment of the agricultural industry [54]. This study suggested that agroecological projects, workshops, seminars, and training events should be conducted continuously. This would provide the opportunity for farmers and workers to increase their knowledge, thus encouraging them to gradually adopt more advantageous agripractices for sustainability and improved food security [56].

However, it should be noted that poorly developed countries can lack incentives that cause growth and agricultural efficiency. It should be stressed that, apart from assistance at the national level, alleviating the global problem of hunger requires the participation of the international community [57]. 
A summary of the sustainability drivers and pragmatic interventions associated with agriculture, including livestock agendas, is illustrated in Table 2.

\subsection{Sustainable Food Security Drivers and Pragmatic Interventions in the Manufacturing Sector}

Manufacturing is the most substantial contributor to the environmental impact categories, including water, energy, land usage, acidified air emission, ozone depletion, global warming potential, and waste generation [59].

A striking result shown in Table 3 is the relevance of both recycling and quality improvement as the interventions within input and output resource management. The closed-loop supply chain model is a novel intervention used to intigate the realization of sustainable operations that positively affected profitability (15-year operation lifetime that breaks even in a maximum 10-year payback time), the energy self-sufficiency indicator (cogeneration plant is completely self-sufficient in electric energy), and the employment possibilities [60]. Postfarm gate recycling processes and the optimization of the performance of packaging utilizations are among the pragmatic interventions, which can reduce the environmental impact [59-62].

Another form of recycling process was located, which is by investigating the potential of reusing reconditioned water to reduce wastes and save costs [61,62]. For example, water was successfully recovered in the dairy industry via a combination of ultrafiltration and reverse osmosis processes.

From the perspective of managing the manufacturing practices in the context of sustainable food security, Ocampo [63] identified seven sustainable manufacturing practices. These were ranked in the following order: total quality management, resource efficiency, material efficiency, just-in-time, green manufacturing, waste elimination at source, and ecoefficiency. In the food industry, quality management and innovation have shown a significant impact on green performance [64]. Ocampo [63] suggested that total quality management was the most suitable intervention as it focuses on meeting customer expectations of integrating sustainability considerations in finished food products.

The trends in literature show that food waste produced from manufacturing can come from unavoidable waste (e.g., animal fat, slaughter waste) and have no-value final products [59]. The results postulated that major drivers and interventions are based on the input resource management, where product waste was cited the most. In the recent advances of integrated systems, quality management approach has become more a conventional intervention in the manufacturing sector in addressing the waste issues $[65,66]$.

The conventional purpose of a quality improvement program in the food industry is to improve product quality and to reduce production costs by minimizing variations and reducing wastes [67]. Nevertheless, the purpose was revolutionalized to support the effort for green food production, primarily by reducing wastes effectively $[65,66,68]$. Powell et al. [65] demonstrated the success of lowering milk loss and subsequently, reducing wastewater. Food waste (environmental impact) reduction was implemented through the use of basic quality tools, such as brainstorming, process flow, project charter, key performance indicators, measurement system analysis, material balance analysis, critical-to-quality, cause and effect figure, design of experiment, Pareto chart, control chart, mistake proofing, lean tools such as value stream mapping (VSM), and the six sigma tools, such as statistical process control (SPC) through define, measure, analyze, improve, and control (DMAIC) [65,68]. 
Table 2. Summary of sustainable food security drivers and pragmatic interventions in the agricultural sector.

\begin{tabular}{|c|c|c|c|c|c|}
\hline $\begin{array}{l}\text { Sustainable Food } \\
\text { Security Drivers }\end{array}$ & $\begin{array}{l}\text { Food Security } \\
\text { Domain }\end{array}$ & $\begin{array}{l}\text { Sustainability } \\
\text { Domain }\end{array}$ & $\mathbf{n}$ & Pragmatic Intervention & Reference \\
\hline \multicolumn{6}{|c|}{ Output Management } \\
\hline \multirow{7}{*}{ Yield optimization } & \multirow{7}{*}{$\begin{array}{l}\text { Accessibility } \\
\text { Utilization } \\
\text { Availability }\end{array}$} & \multirow{7}{*}{$\begin{array}{l}\text { Economic Social } \\
\text { Environmental }\end{array}$} & \multirow{7}{*}{8} & System of Rice Intensification & $\begin{array}{l}\text { Mishra et al. [50] } \\
\text { Nkomoki et al. [51] }\end{array}$ \\
\hline & & & & Double/intercropping & Qi and Dang [47] \\
\hline & & & & \multirow{5}{*}{$\begin{array}{l}\text { Agroforestry } \\
\text { Upgrading strategies } \\
\text { Proper seed selection according to climate } \\
\text { and region } \\
\text { Sustainable agricultural intensification } \\
\text { practices }\end{array}$} & Qi et al. [53] \\
\hline & & & & & Nkomoki et al. [51] \\
\hline & & & & & Schindler et al. [32] \\
\hline & & & & & Frimawaty et al. [43] \\
\hline & & & & & Western [52] \\
\hline \multicolumn{6}{|c|}{ Food Security Governance Involvement } \\
\hline Policy towards food security & $\begin{array}{l}\text { Accessibility } \\
\text { Utilization } \\
\text { Availability }\end{array}$ & $\begin{array}{l}\text { Economic, social and } \\
\text { environment }\end{array}$ & 5 & Subsidy and assistance programs & $\begin{array}{l}\text { Qi and Dang [47] } \\
\text { Rosdiana et al. [44] } \\
\text { Frimawaty et al. [43] } \\
\text { Mulema et al. [45] } \\
\text { Yuan et al. [46] }\end{array}$ \\
\hline Evidence base decision & \multirow{5}{*}{$\begin{array}{l}\text { Accessibility } \\
\text { Utilization }\end{array}$} & \multirow{5}{*}{ Social } & 1 & $\begin{array}{l}\text { Field study of environmental performance } \\
\text { and sustainability of agricultural production }\end{array}$ & Skaf et al. [48] \\
\hline \multirow{4}{*}{ Information sharing } & & & \multirow{4}{*}{6} & \multirow{4}{*}{ Training } & $\begin{array}{l}\text { Schindler et al. [32] } \\
\text { Elisante et al. [56] }\end{array}$ \\
\hline & & & & & Zhang et al. $[54,54]$ \\
\hline & & & & & $\begin{array}{l}\text { Mulema et al. [36] } \\
\text { Mishra et al. [41] }\end{array}$ \\
\hline & & & & & Western [52] \\
\hline
\end{tabular}


Table 2. Cont.

\begin{tabular}{|c|c|c|c|c|c|}
\hline $\begin{array}{l}\text { Sustainable Food } \\
\text { Security Drivers }\end{array}$ & $\begin{array}{l}\text { Food Security } \\
\text { Domain }\end{array}$ & $\begin{array}{l}\text { Sustainability } \\
\text { Domain }\end{array}$ & $\mathbf{n}$ & Pragmatic Intervention & Reference \\
\hline \multicolumn{6}{|c|}{ Income Improvement } \\
\hline Fair trade & Stability & EconomicSocial & $\begin{array}{l}1 \\
2\end{array}$ & $\begin{array}{l}\text { Market participation } \\
\text { Self-determination of price }\end{array}$ & $\begin{array}{l}\text { Schindler et al. [32] } \\
\text { Zhang et al. [54] } \\
\text { Galipeau [49] }\end{array}$ \\
\hline Livestock management & Stability & & 1 & $\begin{array}{l}\text { Hen vaccination, use of hybrid layer hens, } \\
\text { and layer hens housing facilities }\end{array}$ & Dumas et al. [28] \\
\hline Land status & Availability & & 3 & $\begin{array}{l}\text { Provide land ownership and tenure } \\
\text { agreement terms }\end{array}$ & $\begin{array}{l}\text { Charoenratana et al. [55] } \\
\text { Nkomoki et al. [51] } \\
\text { Schindler et al. [32] }\end{array}$ \\
\hline \multicolumn{6}{|c|}{ InputResource Management } \\
\hline Materials & Availability & Environment & 2 & Use of organic pesticide & $\begin{array}{l}\text { Elisante et al. [56] } \\
\text { Frimawaty et al. [43] }\end{array}$ \\
\hline & & & 1 & Use of organic fertilizer & Frimawaty et al. [43] \\
\hline Water management & Availability & Environment & $\begin{array}{l}1 \\
1\end{array}$ & $\begin{array}{l}\text { Rainwater harvesting } \\
\text { Rainwater management (RWM) practices }\end{array}$ & $\begin{array}{l}\text { Schindler et al. [32] } \\
\text { Mulema et al. [36] }\end{array}$ \\
\hline Technology & $\begin{array}{l}\text { Accessibility } \\
\text { Utilization }\end{array}$ & $\begin{array}{l}\text { Economi } \\
\text { cSocial }\end{array}$ & 1 & Internet of things (IoT) & Kaur $[58]$ \\
\hline
\end{tabular}


Table 3. Summary of sustainable food security drivers and pragmatic intervention associated with the food manufacturing sector.

\begin{tabular}{|c|c|c|c|c|c|}
\hline $\begin{array}{l}\text { Sustainable Food } \\
\text { Security Drivers }\end{array}$ & Food Security Domain & Sustainability Domain & $\mathbf{n}$ & Pragmatic Intervention & Reference \\
\hline \multicolumn{6}{|c|}{ Input Resource Management } \\
\hline Energy & Availability & Environment & 1 & $\begin{array}{l}\text { Biogas } \\
\text { Cogeneration plant }\end{array}$ & Sgarbossa and Russo [60] \\
\hline & & & & Biogas & Asem-Hiablie et al. [59] \\
\hline Water & Availability & Environment & 4 & Ultrafiltration & Meneses and Flores [62] \\
\hline & & & & $\begin{array}{l}\text { Reverse osmosis system } \\
\text { Packaging material }\end{array}$ & Nugroho Soebandrija [61] \\
\hline Material & Availability & Economic Environment & 1 & $\begin{array}{l}\text { optimization/usage } \\
\text { reduction }\end{array}$ & Asem-Hiablie et al. [59] \\
\hline Costing & $\begin{array}{l}\text { Accessibility } \\
\text { Availability }\end{array}$ & Economic Environment & 1 & Recycling & Asem-Hiablie et al. [59] \\
\hline \multirow[t]{2}{*}{ Product quality and waste } & \multirow{2}{*}{$\begin{array}{l}\text { Accessibility } \\
\text { Availability }\end{array}$} & Economic Environment & 2 & Quality Management & $\begin{array}{l}\text { Pipatprapa et al. [64] } \\
\text { Cotrim et al. [68] }\end{array}$ \\
\hline & & Economic Environment & 2 & Lean Six Sigma & $\begin{array}{l}\text { Powell et al. [65] } \\
\text { Dora and Gellynck et al. [66] }\end{array}$ \\
\hline \multicolumn{6}{|c|}{ Output Management } \\
\hline Production waste & $\begin{array}{c}\text { Accessibility } \\
\text { Availability Utilization }\end{array}$ & Economic Environment & 2 & $\begin{array}{l}\text { Nonstandard product } \\
\text { inspection machine } \\
\text { Recycling }\end{array}$ & $\begin{array}{l}\text { Nugroho Soebandrija [61] } \\
\text { Asem-Hiablie et al. [59] }\end{array}$ \\
\hline Information sharing & Accessibility Utilization & Social & 2 & $\begin{array}{l}\text { Lean Six Sigma } \\
\text { Brainstorming }\end{array}$ & $\begin{array}{l}\text { Powell et al. [65] } \\
\text { Dora and Gellynck et al. [66] }\end{array}$ \\
\hline
\end{tabular}


In principle, Lean Six Sigma (LSS) has a positive effect on sustainable food sustainability, incorporating two solid Lean and Six Sigma as quality [65,66]. The LSS can promote process capability, employee's engagement, empowerment, and educate employees on the consequences of waste $[32,45,50,52,54,66,69-71]$.

The soft benefits of the quality improvement techniques include being able to educate the employees on the consequence of waste, and how to minimize wastes as quality improvement programs that promote employee involvement in the process $[32,45,50,52,54]$ The sustainability drivers and the pragmatic interventions associated with manufacturing are summarized in Table 3.

\subsection{Sustainable Food Security Drivers and Pragmatic Interventions in the Food Logistics Sector}

The result postulated that the logistics affected mostly on the accessibility category of food security principles driven by input, output resource management, and food security governance involvement. Transportation costs and greenhouse gas (GHG) emissions are the dominant paradigm in the food logistics and distribution process [72-74]. Effective food distribution for business today not only considers the operation base, shelf-time, organoleptic and biophysical characteristics, but also must be economically efficient and environmentally friendly. The intervention that enables minimization of carbon dioxide emissions and distribution costs is through reassessment of distribution [73]. Evidently, the feature that makes food supply chains unique and more daunting than perishability is the intense heterogeneity of the industry, with hundreds of thousands of small producers supplying tens of thousands of middle players serving thousands of sale points, and hundreds of retailers each operating a distribution chain [75].

The impact of logistics performance on food security varies according to region [76-78]. In South Africa, the delivery infrastructure impaired rural food security due to poor road conditions, which threatened personnel safety and security. As a result, food shelf-life in retail was shortened due to late delivery or even no distribution at all to some remote counties [72]. Complications from such problems often lead to higher food prices, and the lack of nutrient diversification at retail levels. In order to meet the challenges, food policy intervention at different levels, including infrastructural development, support of entrepreneurship, adaptive production, land reformation, and skill-building needs to be brought to the forefront so as to achieve better food security states [75,79-81]. The sustainability drivers and interventions associated with food logistics are summarized in Table 4 . 
Table 4. Summary of sustainable food security drivers and intervention associated with the food logistics sector.

\begin{tabular}{|c|c|c|c|c|c|}
\hline Sustainable Food Security Drivers & Food Security Domain & Sustainability Domain & $\mathbf{n}$ & Pragmatic Intervention & Reference \\
\hline \multicolumn{6}{|c|}{ Input Resource Management } \\
\hline Costing & Accessibility & Economic and social & 1 & $\begin{array}{l}\text { Distribution route } \\
\text { improvement design }\end{array}$ & Vorotnikov et al. [74] \\
\hline \multicolumn{6}{|c|}{ Output Management } \\
\hline Greenhouse gaseous emission & Availability & Environment & 1 & $\begin{array}{l}\text { Distribution route } \\
\text { improvement design }\end{array}$ & Validi et al. [73] \\
\hline \multicolumn{6}{|c|}{ Food Security Governance Involvement } \\
\hline Financial assistance & Accessibility Utilization & Social & 1 & $\begin{array}{l}\text { Incentives } \\
\text { Grants } \\
\text { Subsidy and assistance } \\
\text { programs }\end{array}$ & Pereira et al. [72] \\
\hline
\end{tabular}




\subsection{Sustainable Drivers and Pragmatic Interventions in the Retail and Restaurant Sector}

In the retail and restaurant sector, food loss/waste, locations, and food prices critically affect food security through high food waste volume [82-84].

"Take back" agreement at the retail level is deemed to be the culprit of food waste generation, particularly bakery items [82]. In business terms, suppliers often agree to take back products that are of unsatisfactory quality or approaching expiry. Meanwhile, at the restaurant level, food waste generation is invariably due to low-quality products, e.g., overripe and underripe produce from suppliers. An innovative approach to avoid the rejected food from becoming food wastes, the function of the food is often changed to animal feed, and the source of biogas [85].

It was observed that poor green practices in the restaurant are believed to be the main cause of food wastes [84,85]. First-in-first-out (FIFO) policy is a highly recommended practice to avoid wilted and spoilt food, especially salad and steak, that are usually prepared at the earliest stage of food preparation [84]. The lack of communication with the customers in informing them about the size or portions also led to food waste generation [84]. According to Pulkkinen et al. [83], consumers are willing to choose low carbon footprint meals if they were informed and given an option. The lack of green practices information was also found to disappoint consumers, thereby highlighting the importance of communication as an intervention to avoid food wastes [85].

Schubert et al. [85] ranked the important green practices or interventions at the restaurants from the consumer's perspective. Reducing energy usage and wastes, using biodegradable or recycled products, serving locally grown food, and using organic products are the top four practices expected by consumers. The least mentioned interventions were donations to environmental projects and paying fees to reduce their ecological footprints.

Food insecurity also affects the different groups of the population, e.g., low-income and senior citizens, who may be affected by limited food choices, financial aids program availability, location of restaurants, and retail and food prices [86]. Thus, a subsidy program such as Nutrition North Canada was introduced to reduce the burden of the cost of nutritious food for residents living in remote areas. Nonetheless, [87] emphasized that the success of such subsidy programs depended on the managers and retailers who were responsible for the full accountability of such programs, such as claims accuracy, transparent fiscal reporting, retail competitions, and prohibitive freight costs. The summary of these sustainability drivers and interventions associated with manufacturing is illustrated in Table 5. 
Table 5. Summary of sustainable food security drivers and intervention in the food retail and restaurant sector.

\begin{tabular}{|c|c|c|c|c|c|}
\hline Sustainable Food Security Drivers & Food Security Domain & Sustainability Domain & $\mathbf{n}$ & Pragmatic Intervention & Reference \\
\hline \multicolumn{6}{|c|}{ Input resource management } \\
\hline \multirow[t]{3}{*}{ Materials } & Availability & Environment & 1 & \multirow{4}{*}{$\begin{array}{l}\text { Use of biodegradable or } \\
\text { recycled products } \\
\text { Use of organic products } \\
\text { Serve locally grown food } \\
\text { First-in-first-out } \\
\text { Installation of } \\
\text { energy-saving facilities }\end{array}$} & Schubert et al. [85] \\
\hline & Accessibility & Environment & $\begin{array}{l}1 \\
1\end{array}$ & & $\begin{array}{l}\text { Cheng et al. [88] } \\
\text { Schubert et al. [85] }\end{array}$ \\
\hline & Utilization & Social & 1 & & Charlebois et al. [84] \\
\hline Energy & Availability & Environment & 1 & & Cheng et al. [88] \\
\hline \multicolumn{6}{|c|}{ Output Management } \\
\hline Food lost/wastages & Availability & Economic Environment & 1 & $\begin{array}{l}\text { Standard operating } \\
\text { procedure compliance }\end{array}$ & Charlebois et al. [84] \\
\hline & & & 1 & $\begin{array}{l}\text { "Take back" agreement } \\
\text { terms }\end{array}$ & Eriksson et al. [82] \\
\hline Healthy and balance diet meal & $\begin{array}{l}\text { Accessibility } \\
\text { Utilization }\end{array}$ & Social & 1 & $\begin{array}{l}\text { Provision of variety and } \\
\text { healthy meals }\end{array}$ & Cheng et al. [88] \\
\hline Information sharing & $\begin{array}{l}\text { Accessibility } \\
\text { Utilization }\end{array}$ & Social & 3 & $\begin{array}{l}\text { Public awareness and } \\
\text { education program }\end{array}$ & $\begin{array}{l}\text { Galloway [87] } \\
\text { Charlebois et al. [84] } \\
\text { Pulkkinen et al. [83] }\end{array}$ \\
\hline \multicolumn{6}{|c|}{ Food Security Governance Involvement } \\
\hline Assistance & $\begin{array}{l}\text { Accessibility } \\
\text { Utilization } \\
\text { Accessibility }\end{array}$ & $\begin{array}{c}\text { Economic } \\
\text { Social Environment }\end{array}$ & 2 & $\begin{array}{l}\text { Subsidy and assistance } \\
\text { programs }\end{array}$ & $\begin{array}{l}\text { Galloway [87] } \\
\text { Oemichen and Smith [86] }\end{array}$ \\
\hline
\end{tabular}




\section{Discussion}

This research focuses on the sustainable food security drivers in their practical interventions in the context of FSC, and further suggests mediator intervention to improve the state of sustainable food security.

\subsection{Sustainable Food Security Drivers in the FSC}

The inextricable relation of food security and sustainability with the drivers in the sustainable food security system is summarized in Figure 7, and these drivers are consistent with several significant studies on sustainable food security $[27,89,90]$. Past literature has shown the interrelationships between the food security pillars and sustainability domain, and mapped by Berry [6], i.e., environmental domain is interrelated with the availability pillar, economy domain is interrelated with the accessibility pillar, whereas social domain is interrelated with the accessibility and utilization pillars. However, further mapping of drivers into these pillars and domains remains a challenge, as particular drivers may relate to the various pillars of food security, as discussed in Section 3.2. Thus, FSC should be flexible in categorizing the drivers and implement suitable pragmatic interventions that may contribute to multiple food security pillars [26,91].

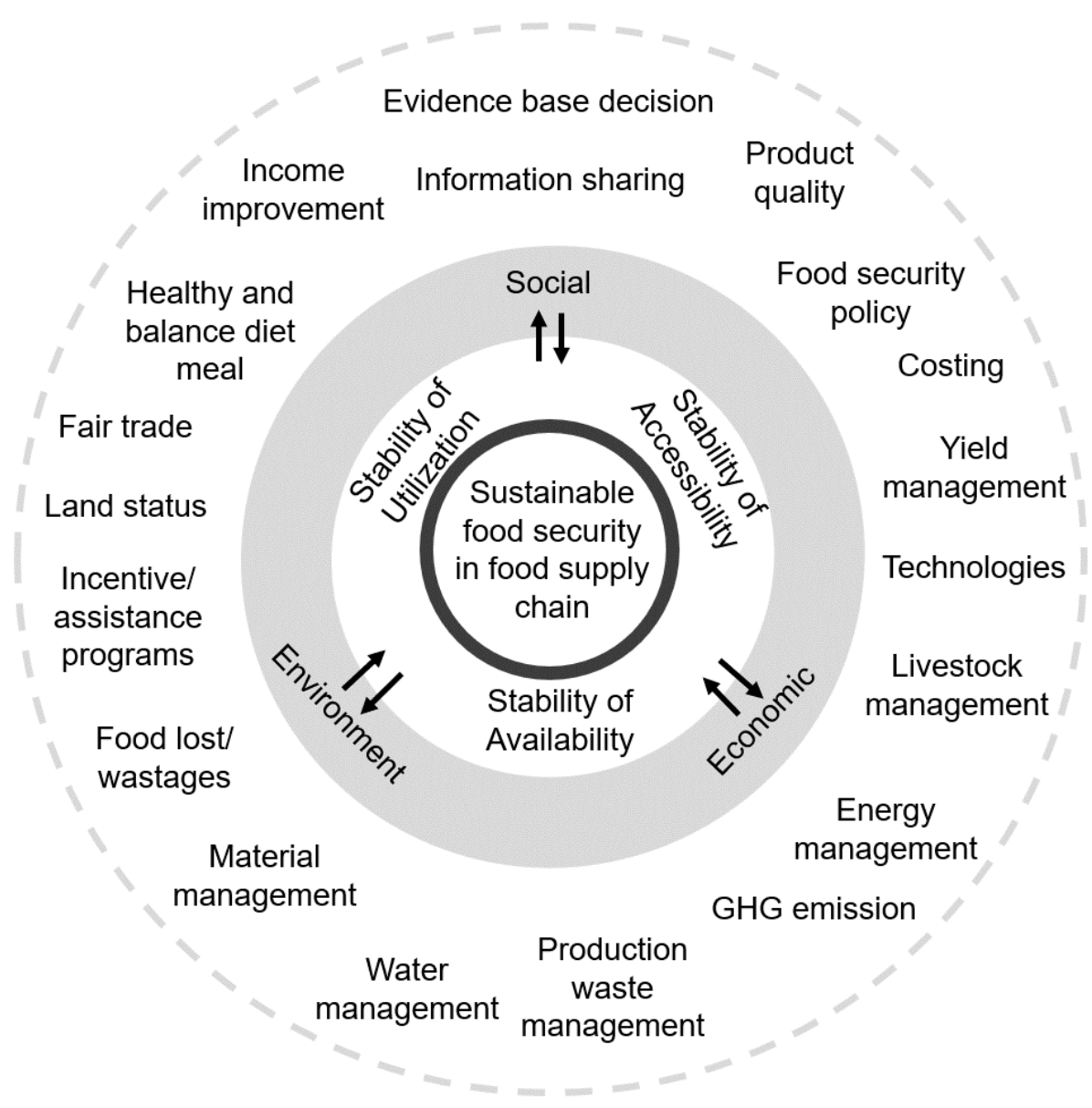

Figure 7. Drivers of the sustainable food security system with the association of food security and sustainability concept.

Further analyzing the commonality of food security drivers themes between each FSC sector (see Table 6), this study identified that the trends of food security in FSC are affected by sustainable food security drivers: (i) food security governance involvement, (ii) input resource management, (iii) output management, and (iv) information sharing. 
Table 6. Common sustainable food security drivers at every sector in FSC.

\begin{tabular}{|c|c|c|c|c|}
\hline & \multicolumn{4}{|c|}{ FSC sector } \\
\hline & Agriculture/Livestock & Manufacturing & Logistics & $\begin{array}{l}\text { Retail and } \\
\text { Restaurant }\end{array}$ \\
\hline $\begin{array}{l}\text { Food security } \\
\text { governance involvement }\end{array}$ & $\checkmark$ & $X$ & $\boldsymbol{\sim}$ & $\checkmark$ \\
\hline $\begin{array}{l}\text { Input resource } \\
\text { management }\end{array}$ & $\boldsymbol{\nu}$ & $\checkmark$ & $\boldsymbol{\sim}$ & $\boldsymbol{V}$ \\
\hline Output management & $\boldsymbol{V}$ & $\checkmark$ & $\checkmark$ & $\checkmark$ \\
\hline Information sharing & $\boldsymbol{\nu}$ & $\checkmark$ & $x$ & $\checkmark$ \\
\hline
\end{tabular}

The first driver for sustainable food security illustrated the importance of food security governance involvement in ensuring the proper allocation of resources, and that the decisions were made based on clear evidence. The notion of food security governances can be referred to formal and informal rules and processes through public and private actors articulating their interests, and decisions for achieving food and nutrition security (at local, national, and global level) are made and implemented [30,92]. The involvement of food security governance exhibits its potent effects on the success of a sustainable food security system within the FSC through established policy, assistance programs, and facilities resources, e.g., subsidy, grant, and incentive. Food security governance must portray several leadership criteria, including (i) accountability, (ii) making evidence-based decisions, (iii) resource management, and (iv) readiness to collaborate and cooperate with relevant interested parties [14,87,92-95].

Information sharing, likewise, is significantly addressed in the agriculture, manufacturing, and restaurant and retail sectors, but not in the logistics sector (Table 4). Hence, effective information sharing is deemed as one of the sustainable variables in the achievement of food security targets [96]. For instance, without sufficient information-sharing with relevant parties, the distribution route improvement design by Vorotnikov et al. [74] and Validi et al. [73] would have failed. Information should be shared and received by internal and external interested parties, and stakeholders including, but not limited to, suppliers, workers, and internal/external customers (ISO 9000:2015). Various effective information-sharing platforms, e.g., electronic websites, signboards, training, seminars, workshops, and marketing point-of-purchase displays should be fully utilized to ensure that each organization is capable of demonstrating utmost sustainable food security performance.

Input resource management and output management are commensal variables, which postulate involvement in every sector within the FSC. Input resources, be it renewable, nonrenewable, or costing, should be utilized most effectively and efficiently [97]. In this context, effectiveness is defined as the extent to which customer requirements or intended objectives are met. At the same time, efficiency is the measurement of how the organization's resources and efforts are economically utilized when meeting customer satisfaction or intended goals $[98,99]$. Waste output, be it food waste or processing waste, shall be minimized through innovative approaches, including reusing, regenerating, recycling, reducing, or substituting with less harmful alternatives, while maintaining optimum yield and quality (including food safety and nutrition) in fulfilling food security goals [100,101].

Intervention variables could be hypothesized as mediators in the relationship between the exogenous variables and food security states with the reason of intervention. This explains how such exogenous variables could affect the dependent variables (food security state) [102]. Costs (input resource) would have an impact on food security states in areas that have difficulties in self-sufficiency meat (independent meat source) [74]. Redesigning the distribution route is one of the interventions in which minimizing the usage of fuel could lower the price of food, while maximizing the delivery volume could increase the volume of food with affordable prices that can be purchased by remote villages. This helps to improve the food security states. In addition, managing restaurant food losses (exogenous variable) is vital for the betterment of food security (dependent variable) $[41,84]$. Compliance to standard operating procedures in restaurants, e.g., following the first-in-first-out (FIFO) 
method could prevent food wastage and resource depletion. This intervention explains how the independent variable is exerting its effect on the dependent variable.

It was identified that across the four stages of FSC, several drivers are customized for the specific stage of the food chain. Quality management that was categorized under both output and input drivers, however, is the most common driver towards achieving sustainable food security at all stages of FSC, with reducing waste as the focal point. Therefore, this study proposes quality management practices that have an impact on food security state.

\subsection{Role of Quality Management (QM) Intervention in Sustainable Food Security}

It was identified that food waste, quality, and costing are common issues of food securities across the supply chain. Reducing cost and waste are able to be achieved with the implementation of quality management approaches. Quality management is, therefore, an appropriate strategy that could be introduced in the FSC, because quality management is underpinned by four key variables: information management, input processing, output management, and participation of top management $[63,64,68,103]$. As a matter of fact, these variables have been identified as part of the total quality management (TQM) success criteria, alongside employee competency, the voice of the customer, organization identity, engagement and empowerment, relationship management, performance evaluation, and analysis and infrastructure [104] (see Figure 8). In addition, this conceptual model with QM proposed as the mediator aligns with the systematic review of Siva et al. [105], who illustrated that daily sustainability management, including an environmental management system (EMS) with satisfying stakeholder requirements, are facilitated by the QM implementation. Even so, this paper only discussed the contribution of QM towards sustainability without a food security context. In another study, Maistry et al. [103] concluded that by using structural equation modelling (SEM) where the TQM has the highest total effect on organization sustainable performance also contributes towards organization strategy via employee engagement and empowerment.

The concept of quality management in the food industry is covered in vast areas, and it involves several systems, with the term used to depict TQM, Lean, Six Sigma, ISO, and Quality Assurance [98]. Nevertheless, Luning and Marcelis [106] defined the overall food quality management concept model as consisting of five aspects:

1. Quality design, such as quality function development (QFD), failure mode, and effect analysis (FMEA), which formulates the standards in meeting customer, interested parties, or stakeholder requirements.

2. Quality control, such as statistical process control (SPC), which ensures output meets customer, interested parties, or stakeholder requirements.

3. Quality improvement, such as Sigma, Lean Six Sigma, and dashboard metrics, as a method to continually improve in every aspect to meet or exceed customer, interested parties, or stakeholder requirements.

4. Quality assurance, such as such as Hazard Analysis Critical Control Point (HACCP), ISO, British Retail Consortium (BRC), which ensures and verifies the processes capability in meeting customer, interested parties, or stakeholder requirements.

5. Quality policy and strategy, which define directions and internal responsibilities to achieve customer, interested parties or stakeholder requirements.

World-renowned ISO 9001 Quality Management System (QMS) demonstrated its ability to consistently provide quality products and services that meet customer and applicable statutory and regulatory requirements (ISO 9001:2015). Improving product quality tends to create added value in sustainability. For instance, improvement of economic benefits via sales increment, and social benefits via the fulfilment of public environmental concern needs [107]. Furthermore, the QMS is also considered as the starting point of Environment Management System ISO 14001, Social Accountability (SA 8000), and Occupational Health and Safety (ISO 45001) [68]. Wiengarten and Pagell [108] concluded 
that higher performance in environmental management in terms of cost, flexibility, and delivery performance is achieved by organizations that practice quality management systems. In a study by Strotmann et al. [109], adapting PDCA (plan-do-check-act) is seen as a intervention developed via an implementation framework that assists the FSC's managers in reducing food wastes.

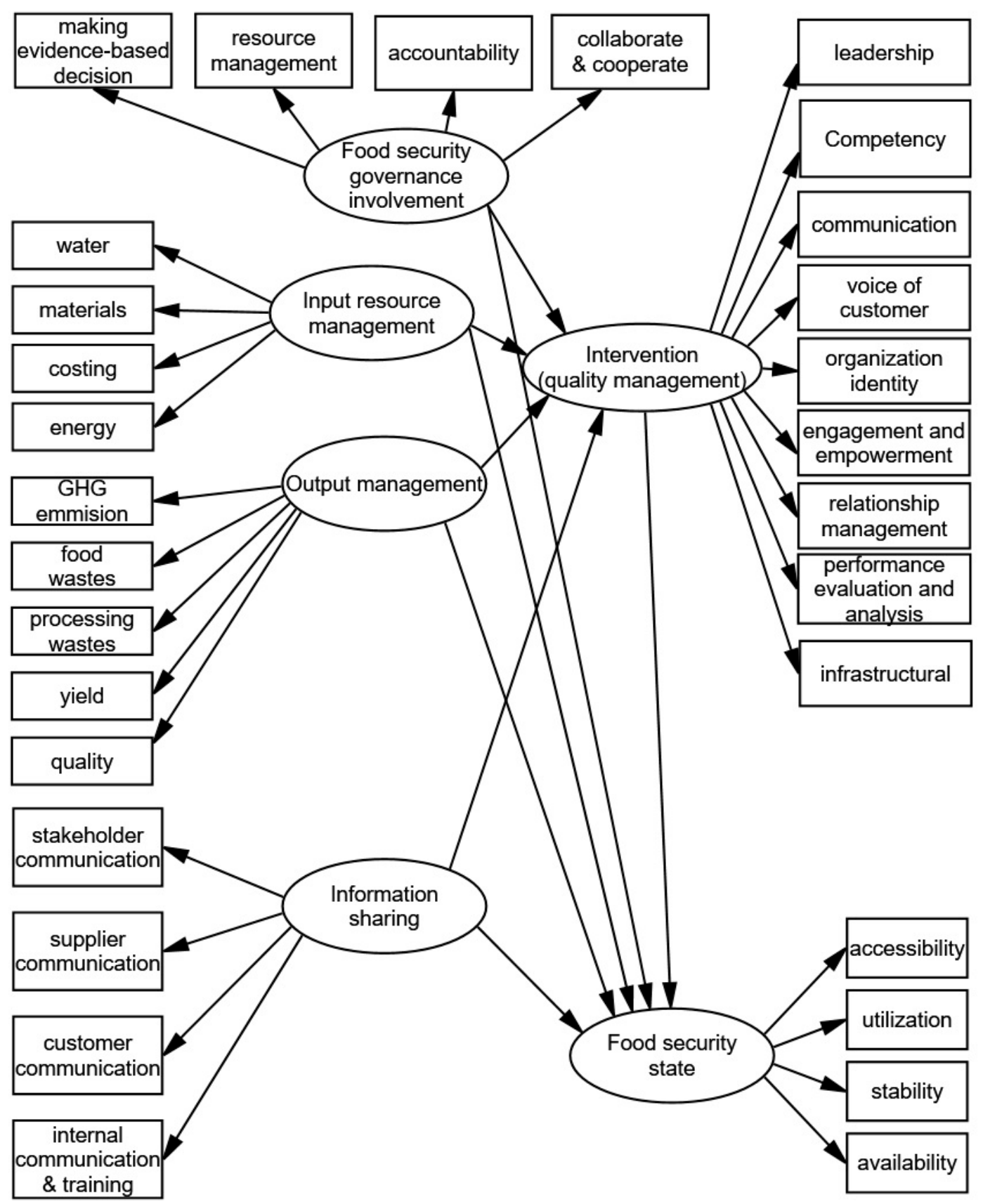

Figure 8. Conceptual model of sustainable food security system.

Started with TQM, Lean and Six Sigma are the renowned approaches to improving operational performance across industries, and now also serve environmental purposes [66]. The conventional Lean concept tackles seven wastes in an organization, and capable in facilitating cleaner and sustainable productions [71]. Likewise, Six Sigma, which is originally a disciplined, project-oriented, data-driven approach, can be used to reduce variations and defects in a process via the DMAIC methodology [110]. Such an application has evolved to implement innovative programs that simultaneously enhance 
environmental performance and provides tremendous cost savings [111]. While Lean is known for its strength in waste elimination through the usage of TQM, value stream mapping (VSM) and just-in-time (JIT) in supply chain $[94,112]$ waste elimination, and TQM demonstrated significant correlations on all three dimensions of sustainability. The Six Sigma method (DMAIC) and tools (cause-and-effect diagram) have been successfully adopted by Kandananond [113] to systematically reduce water footprints in the agricultural sector.

\section{Conclusions}

This paper sought to identify trends in publications in the direction of sustainable food security by examining its drivers that are critical for shaping food policy. Four main drivers were identified from this systematic review of 40 articles; these reflect the sustainability drivers and the interventions practiced by each sector in the FSC.

The first driver focused on the critical role of food security governance, especially for agriculture, logistics, retailers, and restaurants. The second driver explained the importance of effective management of the input resources, e.g., water, biosafety materials, and energy via various innovative interventions. The third theme highlighted output management, especially on food waste reduction and GHG reduction. The fourth theme was the labor income gained through fair trade, which directly impacts farm workers. Based on the analysis, quality management was also identified as a hypothetic generic intervention that could mediate the effect of these familiar drivers towards food security in the FSC.

In general, previous literature had postulated a conceptual model of sustainable food security drivers in the context of FSC. Further effort to improve the new developments is suggested to generalize the result through statistical analysis, e.g., structural equation modeling (SEM). In addition, the definition of sustainable food security in this study is "individual ability to acquire foods that satisfy human nutritional needs without compromising the human and environmental health at all times. The food supply chain can implement effective practices that would improve the state of sustainable food security, such as food security governance involvement, input resource management, output management, and information sharing." This definition is necessary because the existing food security definition does not proclaim the participatory role of the sustainability concept. This study provides a profound understanding of the sustainable drivers and interventions towards food security and further provides new innovative solutions to food security issues through the implementation of quality management practices.

Author Contributions: Writing-original draft preparation, methodology, and formal analysis, H.Y.C.; Conceptualization, project administration, resources, and funding acquisition, S.A.H.-L.; Writing-review and editing, T.B.T.; Supervision, N.H.K.; Software and data curation, A.A.J.; Visualization, W.A.A.Q.I.W.-M. All authors have read and agreed to the published version of the manuscript.

Funding: This work is supported by the Malaysia Ministry of Education (MOE) for providing research grant under Fundamental Research Grant Scheme (FRGS/1/2018/TK03/UPM/02/7), Universiti Putra Malaysia under research grant Putra Young Initiative (IPM/2017/9552400), and GERAN RU-SATU (Southeast and South Asia and Taiwan Universities) JOINT RESEARCH 2020: ST002-2020 Universiti Malaya.

Conflicts of Interest: The authors declare no conflict of interest. The funders had no role in the design of the study; in the collection, analyses, or interpretation of data; in the writing of the manuscript, or in the decision to publish the results.

\section{References}

1. Shaw, D.J. World Food Conference 1974. In World Food Security: A History Since 1945; Palgrave Macmillan UK: London, UK, 2007; pp. 121-149. ISBN 978-0-230-58978-0.

2. Ecker, O.; Diao, X. Food Security Policy Brief. Available online: http://www.fao.org/fileadmin/templates/ faoitaly/documents/pdf/pdf_Food_Security_Cocept_Note.pdf (accessed on 18 September 2020).

3. Mechlem, K. Food Security and the Right to Food in the Discourse of the United Nations. Eur. Law J. 2004, 10, 631-648. [CrossRef] 
4. Lang, T.; Barling, D. Food security and food sustainability: Reformulating the debate. Geogr. J. 2012, 178, 313-326. [CrossRef]

5. Capone, R.; El Bilali, H.; Debs, P.; Cardone, G.; Driouech, N. Food System Sustainability and Food Security: Connecting the Dots. J. Food Secur. 2014, 2, 13-22. [CrossRef]

6. Berry, E.M.; Dernini, S.; Burlingame, B.; Meybeck, A.; Conforti, P. Food security and sustainability: Can one exist without the other? Public Health Nutr. 2015, 18, 2293-2302. [CrossRef] [PubMed]

7. Correia, E.; Carvalho, H.; Azevedo, S.G.; Govindan, K. Maturity models in supply chain sustainability: A systematic literature review. Sustainability 2017, 9, 64. [CrossRef]

8. Beske, P.; Land, A.; Seuring, S. Sustainable supply chain management practices and dynamic capabilities in the food industry: A critical analysis of the literature. Int. J. Prod. Econ. 2014, 152, 131-143. [CrossRef]

9. Saint Ville, A.; Po, J.Y.T.; Sen, A.; Bui, A.; Melgar-Quiñonez, H. Food security and the Food Insecurity Experience Scale (FIES): Ensuring progress by 2030. Food Secur. 2019, 11, 483-491. [CrossRef]

10. FAO; IFAD; UNICEF; WFP; WHO. The State of Food Security and Nutrition in the World: Building Climate Resilience for Food Security and Nutrition; FAO: Rome, Italy, 2018.

11. FAO; IFAD; UNICEF; WFP; WHO. The State of Food Security and Nutrition in the World: Building Resilience for Peace and Food Security; FAO: Rome, Italy, 2017.

12. Bastas, A.; Liyanage, K. ISO 9001 and supply chain integration principles based sustainable development: A Delphi study. Sustainability 2018, 10, 4569. [CrossRef]

13. Aiking, H.; de Boer, J. Food sustainability: Diverging interpretations. Br. Food J. 2004, 106, 359-365. [CrossRef]

14. Candel, J.J.L. Food security governance: A systematic literature review. Food Secur. 2014, 6, 585-601. [CrossRef]

15. Sun, F.; DAI, Y.; Yu, X. Air pollution, food production and food security: A review from the perspective of food system. J. Integr. Agric. 2017, 16, 2945-2962. [CrossRef]

16. Irani, Z.; Sharif, A.M. Sustainable food security futures: Perspectives on food waste and information across the food supply chain. J. Enterp. Inf. Manag. 2016, 29, 171-178. [CrossRef]

17. Petticrew, M.; Roberts, H. Systematic Reviews in the Social Sciences: A Practical Guide; John Wiley \& Sons: Hoboken, NJ, USA, 2008; ISBN 1405121106.

18. Mohamed Shaffril, H.A.; Samah, A.A.; Samsuddin, S.F.; Ali, Z. Mirror-mirror on the wall, what climate change adaptation strategies are practiced by the Asian's fishermen of all? J. Clean. Prod. 2019, 232, 104-117. [CrossRef]

19. Halim Lim, S.A.; Antony, J.; Arshed, N.; Albliwi, S. A systematic review of statistical process control implementation in the food manufacturing industry. Total Qual. Manag. Bus. Excell. 2017, 28, 176-189. [CrossRef]

20. Tranfield, D.; Denyer, D.; Smart, P. Towards a Methodology for Developing Evidence-Informed Management Knowledge by Means of Systematic Review. Br. J. Manag. 2003, 14, 207-222. [CrossRef]

21. Younger, P. Using google scholar to conduct a literature search. Nurs. Stand. 2010, 24. [CrossRef]

22. Béné, C.; Oosterveer, P.; Lamotte, L.; Brouwer, I.D.; de Haan, S.; Prager, S.D.; Talsma, E.F.; Khoury, C.K. When food systems meet sustainability—Current narratives and implications for actions. World Dev. 2019, 113, 116-130. [CrossRef]

23. Hecht, A.A.; Biehl, E.; Barnett, D.J.; Neff, R.A. Urban Food Supply Chain Resilience for Crises Threatening Food Security: A Qualitative Study. J. Acad. Nutr. Diet. 2019, 119, 211-224. [CrossRef]

24. Ilbery, B.; Maye, D. Food supply chains and sustainability: Evidence from specialist food producers in the Scottish/English borders. Land Use Policy 2005, 22, 331-344. [CrossRef]

25. Hazell, P.; Wood, S. Drivers of change in global agriculture. Philos. Trans. R. Soc. B Biol. Sci. 2008, 363, 495-515. [CrossRef]

26. Hassen, T.B.; Bilali, H.E.; Al-Maadeed, M. Agri-food markets in Qatar: Drivers, trends, and policy responses. Sustainability 2020, 12, 3643. [CrossRef]

27. Godfray, H.C.J.; Beddington, J.R.; Crute, I.R.; Haddad, L.; Lawrence, D.; Muir, J.F.; Pretty, J.; Sherman, R.; Thomas, S.M.; Toulmin, C. Food Security: The Challenge of Feeding 9 Billion People. Geoforum 2018, 91, 73-77. [CrossRef] [PubMed] 
28. Dumas, S.E.; Lungu, L.; Mulambya, N.; Daka, W.; Mcdonald, E.; Steubing, E.; Lewis, T.; Backel, K.; Jange, J.; Lucio-martinez, B.; et al. Sustainable smallholder poultry interventions to promote food security and social, agricultural, and ecological resilience in the Luangwa Valley, Zambia. Food Secur. 2016, 507-520. [CrossRef] [PubMed]

29. Nicholson, E.; Murphy, T.; Larkin, P.; Normand, C.; Guerin, S. Protocol for a thematic synthesis to identify key themes and messages from a palliative care research network. BMC Res. Notes 2016, 9, 478. [CrossRef] [PubMed]

30. Termeer, C.; Dewulf, A.; Van Rijswick, H.; Van Buuren, A.; Huitema, D.; Meijerink, S.; Rayner, T.; Wiering, M. The regional governance of climate adaptation: A framework for developing legitimate, effective, and resilient governance arrangements. Clim. Law 2011, 2, 159-179. [CrossRef]

31. Braun, V.; Clarke, V. Successful Qualitative Research-A Practical Guide for Beginners; SAGE: Newbury Park, CA, USA, 2013; ISBN 9781847875815.

32. Schindler, J.; Graef, F.; König, H.J.; Mchau, D.; Saidia, P.; Sieber, S. Sustainability impact assessment to improve food security of smallholders in Tanzania. Environ. Impact Assess. Rev. 2016, 60, 52-63. [CrossRef]

33. United Nations. World Population Prospects 2019; United Nations: New York, NY, USA, 2019.

34. U.S. Government. U.S. Government Global Food Security Strategy FY 2017-2021; U.S. Government: Washington, DC, USA, 2016.

35. Siegel, K.M.; Bastos Lima, M.G. When international sustainability frameworks encounter domestic politics: The sustainable development goals and agri-food governance in South America. World Dev. 2020, 135, 105053. [CrossRef]

36. Schwerhoff, G.; Sy, M. Financing renewable energy in Africa-Key challenge of the sustainable development goals. Renew. Sustain. Energy Rev. 2017, 75, 393-401. [CrossRef]

37. Mc Carthy, U.; Uysal, I.; Badia-Melis, R.; Mercier, S.; O’Donnell, C.; Ktenioudaki, A. Global food security-Issues, challenges and technological solutions. Trends Food Sci. Technol. 2018, 77, 11-20. [CrossRef]

38. Mottet, A.; Teillard, F.; Boettcher, P.; De Besi, G.; Besbes, B. Review: Domestic herbivores and food security: Current contribution, trends and challenges for a sustainable development. Animal 2018, 12, S188-S198. [CrossRef]

39. Hassini, E.; Surti, C.; Searcy, C.; Govindan, K.; Kadziński, M.; Sivakumar, R.; Liu, Y.; Wang, S.; Chen, B.; Zanoni, S.; et al. A case analysis of a sustainable food supply chain distribution system-A multi-objective approach. J. Clean. Prod. 2018, 152, 1039-1054. [CrossRef]

40. Petit, G.; Sablayrolles, C.; Yannou-Le Bris, G. Combining eco-social and environmental indicators to assess the sustainability performance of a food value chain: A case study. J. Clean. Prod. 2018, 191, 135-143. [CrossRef]

41. Kummu, M.; de Moel, H.; Porkka, M.; Siebert, S.; Varis, O.; Ward, P.J. Lost food, wasted resources: Global food supply chain losses and their impacts on freshwater, cropland, and fertiliser use. Sci. Total Environ. 2012, 438, 477-489. [CrossRef] [PubMed]

42. Siddh, M.M.; Soni, G.; Jain, R.; Sharma, M.K. Structural model of perishable food supply chain quality (PFSCQ) to improve sustainable organizational performance. Benchmarking 2018, 25, 2272-2317. [CrossRef]

43. Frimawaty, E.; Basukriadi, A.; Syamsu, J.A.; Soesilo, T.E.B. Sustainability of Rice Farming based on Eco-Farming to Face Food Security and Climate Change: Case Study in Jambi Province, Indonesia. Procedia Environ. Sci. 2013, 17, 53-59. [CrossRef]

44. Rosdiana, H. Inayati; Murwendah Evaluation of Fiscal Policy on Agropolitan Development to Raise Sustainable Food Security (A Study Case in Bangli Regency, Kuningan Regency and Batu Municipality, Indonesia). Procedia Environ. Sci. 2014, 20, 563-572. [CrossRef]

45. Mulema, A.A.; Lema, Z.; Damtew, E.; Adie, A.; Ogutu, Z.; Duncan, A.J. Stakeholders' perceptions of integrated rainwater management approaches in the Blue Nile Basin of the Ethiopian highlands. Nat. Resour. Forum 2017, 41, 244-254. [CrossRef]

46. Yuan, C.; Liu, L.; Qi, X. Assessing the impacts of the changes in farming systems on food security and environmental sustainability of a Chinese rural region under different policy scenarios: An agent-based model. Environ. Monit. Assess. 2017. [CrossRef]

47. Qi, X.; Dang, H. Addressing the dual challenges of food security and environmental sustainability during rural livelihood transitions in China. Land Use Policy 2018, 77, 199-208. [CrossRef]

48. Skaf, L.; Buonocore, E.; Dumontet, S.; Capone, R.; Franzese, P.P. Food security and sustainable agriculture in Lebanon: An environmental accounting framework. J. Clean. Prod. 2019, 209, 1025-1032. [CrossRef] 
49. Galipeau, B.A. Balancing Income, Food Security, and Sustainability in Shangri-La: The Dilemma of Monocropping Wine Grapes in Rural China. Cult. Agric. Food Environ. 2015, 37, 74-83. [CrossRef]

50. Mishra, A.; Kumar, P.; Ketelaar, J.W. Improving rice-based rainfed production systems in Southeast Asia for contributing towards food security and rural development through sustainable crop production intensification. AIMS Agric. Food 2016, 1, 102-123. [CrossRef]

51. Nkomoki, W.; Bavorová, M.; Banout, J. Adoption of sustainable agricultural practices and food security threats: Effects of land tenure in Zambia. Land Use Policy 2018, 78, 532-538. [CrossRef]

52. Western, N. Sustainable agricultural intensification practices and rural food security: The Article information. Br. Food J. 2018. [CrossRef]

53. Qi, X.; Fu, Y.; Wang, R.Y.; Ng, C.N.; Dang, H.; He, Y. Improving the sustainability of agricultural land use: An integrated framework for the conflict between food security and environmental deterioration. Appl. Geogr. 2018, 90, 214-223. [CrossRef]

54. Zhang, Q.; Sun, Z.; Wu, F.; Deng, X. Understanding rural restructuring in China: The impact of changes in labor and capital productivity on domestic agricultural production and trade. J. Rural Stud. 2016, 47, 552-562. [CrossRef]

55. Charoenratana, S.; Shinohara, C. Rural farmers in an unequal world: Land rights and food security for sustainable well-being. Land Use Policy 2018, 78, 185-194. [CrossRef]

56. Elisante, F.; Ndakidemi, P.A.; Arnold, S.E.J.; Belmain, S.R.; Gurr, G.M.; Darbyshire, I.; Xie, G.; Tumbo, J.; Stevenson, P.C. Enhancing knowledge among smallholders on pollinators and supporting field margins for sustainable food security. J. Rural Stud. 2019, 70, 75-86. [CrossRef]

57. Pawlak, K.; Kołodziejczak, M. The role of agriculture in ensuring food security in developing countries: Considerations in the context of the problem of sustainable food production. Sustainability 2020, 12, 5488. [CrossRef]

58. Kaur, H. Modelling internet of things driven sustainable food security system. Benchmarking 2019. [CrossRef]

59. Asem-Hiablie, S.; Battagliese, T.; Stackhouse-Lawson, K.R.; Alan Rotz, C. A life cycle assessment of the environmental impacts of a beef system in the USA. Int. J. Life Cycle Assess. 2019, 24, 441-455. [CrossRef]

60. Sgarbossa, F.; Russo, I. A proactive model in sustainable food supply chain: Insight from a case study. Int. J. Prod. Econ. 2017, 183, 596-606. [CrossRef]

61. Nugroho Soebandrija, K.E. Green innovation and sustainable industrial systems within sustainability and company improvement perspective. IOP Conf. Ser. Earth Environ. Sci. 2018, 109. [CrossRef]

62. Meneses, Y.E.; Flores, R.A. Feasibility, safety, and economic implications of whey-recovered water in cleaning-in-place systems: A case study on water conservation for the dairy industry. J. Dairy Sci. 2016, 99, 3396-3407. [CrossRef] [PubMed]

63. Ocampo, L.A. Correction to: Applying fuzzy AHP-TOPSIS technique in identifying the content strategy of sustainable manufacturing for food production. Environ. Dev. Sustain. 2018, 21, 1-2. [CrossRef]

64. Pipatprapa, A.; Huang, H.H.; Huang, C.H. The Role of Quality Management \& Innovativeness on Green Performance. Corp. Soc. Responsib Environ. Manag. 2017, 24, 249-260. [CrossRef]

65. Powell, D.; Lundeby, S.; Chabada, L.; Dreyer, H. Lean Six Sigma and environmental sustainability: The case of a Norwegian dairy producer. Int. J. Lean Six Sigma 2017, 8, 53-64. [CrossRef]

66. Dora, M.; Gellynck, X. Lean Six Sigma Implementation in a Food Processing SME: A Case Study. Qual. Reliab. Eng. Int. 2015, 31, 1151-1159. [CrossRef]

67. Abdul Halim Lim, S.; Antony, J.; He, Z.; Arshed, N. Critical observations on the statistical process control implementation in the UK food industry: A survey. Int. J. Qual. Reliab. Manag. 2017, 34, 684-700. [CrossRef]

68. Cotrim, S.L.; Filho, D.A.M.; Leal, G.C.L.; Galdamez, E.V.C. Implementation of cleaner production along with quality management tools. Int. J. Technol. Manag. Sustain. Dev. 2018, 17, 65-85. [CrossRef]

69. Kader Ali, N.N.; Choong, C.W.; Jayaraman, K. Critical success factors of Lean Six Sigma practices on business performance in Malaysia. Int. J. Product. Qual. Manag. 2016, 17, 456-473. [CrossRef]

70. Kosieradzka, A.; Ciechańska, O. Impact of enterprise maturity on the implementation of six sigma concept. Manag. Prod. Eng. Rev. 2018, 9, 59-70. [CrossRef]

71. Henao, R.; Sarache, W.; Gómez, I. Lean manufacturing and sustainable performance: Trends and future challenges. J. Clean. Prod. 2019, 208, 99-116. [CrossRef]

72. Pereira, L.M.; Cuneo, C.N.; Twine, W.C. Food and cash: Understanding the role of the retail sector in rural food security in South Africa. Food Secur. 2014, 6, 339-357. [CrossRef] 
73. Validi, S.; Bhattacharya, A.; Byrne, P.J. A case analysis of a sustainable food supply chain distribution system-A multi-objective approach. Int. J. Prod. Econ. 2014, 152, 71-87. [CrossRef]

74. Vorotnikov, I.; Sukhanova, I.; Tretyak, L.; Baskakov, S. A logistics model of sustainable food supply of the region. Econ. Ann. 2017, 164, 94-98. [CrossRef]

75. Accorsi, R.; Cholette, S.; Manzini, R.; Tufano, A. A hierarchical data architecture for sustainable food supply chain management and planning. J. Clean. Prod. 2018, 203, 1039-1054. [CrossRef]

76. Colicchia, C.; Strozzi, F. Supply chain risk management: A new methodology for a systematic literature review. Supply Chain Manag. 2012, 17, 403-418. [CrossRef]

77. Hausmann, C.; Patrick, S. Contingency Planning: Trade's Role in Sustainable World Food Security. Aquat. Procedia 2013, 1, 20-29. [CrossRef]

78. Smith, K.; Lawrence, G. Flooding and food security: A case study of community resilience in Rockhampton. Rural. Soc. 2014, 20, 216-228. [CrossRef]

79. Vijayan, G.; Kamarulzaman, N.H.; Mohamed, Z.A.; Abdullah, A.M. Sustainability in food retail industry through reverse logistics. Int. J. Supply Chain Manag. 2014, 3, 11-23.

80. Vanalle, R.M.; Lucato, W.C.; Rodrigues, R.T. The utilization of ISO 9004: Case study of the maintenance area of a public transportation company. J. Qual. Maint. Eng. 2016, 22, 94-111. [CrossRef]

81. Shankar, R.; Gupta, R.; Pathak, D.K. Modeling critical success factors of traceability for food logistics system. Transp. Res. Part E Logist. Transp. Rev. 2018, 119, 205-222. [CrossRef]

82. Eriksson, M.; Ghosh, R.; Mattsson, L.; Ismatov, A. Take-back agreements in the perspective of food waste generation at the supplier-retailer interface. Resour. Conserv. Recycl. 2017, 122, 83-93. [CrossRef]

83. Pulkkinen, H.; Roininen, T.; Katajajuuri, J.M.; Järvinen, M. Development of a Climate Choice meal concept for restaurants based on carbon footprinting. Int. J. Life Cycle Assess. 2016, 21, 621-630. [CrossRef]

84. Charlebois, S.; Creedy, A.; von Massow, M. "Back of house" - focused study on food waste in fine dining: The case of Delish restaurants. Int. J. Cult. Tour. Hosp. Res. 2015, 9, 278-291. [CrossRef]

85. Schubert, F.; Kandampully, J.; Solnet, D.; Kralj, A. Exploring Consumer Perceptions of Green Restaurants in the US. Tour. Hosp. Res. 2010, 10, 286-300. [CrossRef]

86. Oemichen, M.; Smith, C. Investigation of the Food Choice, Promoters and Barriers to Food Access Issues, and Food Insecurity Among Low-Income, Free-Living Minnesotan Seniors. J. Nutr. Educ. Behav. 2016, 48, 397-404.e1. [CrossRef]

87. Galloway, T. Canada's northern food subsidy nutrition north Canada: A comprehensive program evaluation. Int. J. Circumpolar Health 2017, 76, 1-19. [CrossRef]

88. Cheng, C.C.; Chang, Y.Y.; Tsai, M.C.; Chen, C.T.; Tseng, Y.C. An evaluation instrument and strategy implications of service attributes in LOHAS restaurants. Int. J. Contemp. Hosp. Manag. 2019, 31, 194-216. [CrossRef]

89. Godfray, H.C.J.; Garnett, T. Food security and sustainable intensification. Philos. Trans. R. Soc. B Biol. Sci. 2014, 369, 6-11. [CrossRef] [PubMed]

90. Godfray, H.C.J.; Crute, I.R.; Haddad, L.; David, L.; Muir, J.F.; Nisbett, N.; Pretty, J.; Robinson, S.; Toulmin, C.; Whiteley, R. The future of the global food system. Philos. Trans. R. Soc. B Biol. Sci. 2010, 365, 2769-2777. [CrossRef] [PubMed]

91. Borsellino, V.; Schimmenti, E.; El Bilali, H. Agri-food markets towards sustainable patterns. Sustainability 2020, 12, 2193. [CrossRef]

92. Pérez-Escamilla, R.; Gubert, M.B.; Rogers, B.; Hromi-Fiedler, A. Food security measurement and governance: Assessment of the usefulness of diverse food insecurity indicators for policy makers. Glob. Food Sec. 2017, 14, 96-104. [CrossRef]

93. Montoya, L.A.; Montoya, I.; Sánchez González, O.D. Lessons from collaborative governance and sociobiology theories for reinforcing sustained cooperation: A government food security case study. Public Health 2015, 129, 916-931. [CrossRef]

94. Manzouri, M.; Ab-Rahman, M.N.; Zain, C.R.C.M.; Jamsari, E.A. Increasing production and eliminating waste through lean tools and techniques for Halal food companies. Sustainability 2014, 6, 9179-9204. [CrossRef]

95. Jing, X.; Guanxin, Y.; Panqian, D. Quality Decision-Making Behavior of Bodies Participating in the Agri-Foods E-Supply Chain. Sustainability 2020, 12, 1874. [CrossRef] 
96. Olarinde, L.O.; Abass, A.B.; Abdoulaye, T.; Adepoju, A.A.; Adio, M.O.; Fanifosi, E.G.; Wasiu, A. The influence of social networking on food security status of cassava farming households in Nigeria. Sustainability 2020, 12, 5420. [CrossRef]

97. Foley, J.A.; Ramankutty, N.; Brauman, K.A.; Cassidy, E.S.; Gerber, J.S.; Johnston, M.; Mueller, N.D.; O'Connell, C.; Ray, D.K.; West, P.C.; et al. Solutions for a cultivated planet. Nature 2011, 478, 337-342. [CrossRef]

98. Lacerda, T.C.; von Wangenheim, C.G. Systematic literature review of usability capability/maturity models. Comput. Stand. Interfaces 2018, 55, 1339-1351. [CrossRef]

99. Neely, A.; Gregory, M.; Platts, K. Performance measurement system design: A literaturer review. Int. J. Oper. Prod. Manag. 1995, 15, 35. [CrossRef]

100. Carrillo-Labella, R.; Fort, F.; Parras-Rosa, M. Motives, barriers, and expected benefits of ISO 14001 in the agri-food sector. Sustainability 2020, 12, 1724. [CrossRef]

101. Tilman, D.; Balzer, C.; Hill, J.; Befort, B.L. Global food demand and the sustainable intensification of agriculture. Proc. Natl. Acad. Sci. USA 2011, 108, 20260-20264. [CrossRef] [PubMed]

102. Kraemer, H.C.; Kupfer, D.J. How and Why Criteria Defining Moderators and Mediators Differ. Heal. Psychol. 2012, 27, 2. [CrossRef]

103. Maistry, K.; Hurreeram, D.K.; Ramessur, V. Total quality management and innovation: Relationships and effects on performance of agricultural R\&D organisations. Int. J. Qual. Reliab. Manag. 2017, 34, 418-437. [CrossRef]

104. Sreedharan, R.V.; Sunder, V.M.; Raju, R. Critical success factors of TQM, Six Sigma, Lean and Lean Six Sigma: A literature review and key findings. Benchmarking 2018, 25, 3479-3504. [CrossRef]

105. Siva, V.; Gremyr, I.; Bergquist, B.; Garvare, R.; Zobel, T.; Isaksson, R. The support of Quality Management to sustainable development: A literature review. J. Clean. Prod. 2016, 138, 148-157. [CrossRef]

106. Luning, P.A.; Marcelis, W.J. A conceptual model of food quality management functions based on a techno-managerial approach. Trends Food Sci. Technol. 2007, 18, 159-166. [CrossRef]

107. Pamfilie, R.; Bobe, M.; Cristescu, L.; Alexandra Toma, M. Innovative Food Quality Models—Developed as an Interface for Modern Consumers and Sustainable Business. Econ. Interf. 2016, 18, 663-674.

108. Wiengarten, F.; Pagell, M. The importance of quality management for the success of environmental management initiatives. Int. J. Prod. Econ. 2012, 140, 407-415. [CrossRef]

109. Strotmann, C.; Göbel, C.; Friedrich, S.; Kreyenschmidt, J.; Ritter, G.; Teitscheid, P. A participatory approach to minimizing food waste in the food industry-A manual for managers. Sustainability 2017, 9, 66. [CrossRef]

110. Muralidharan, K. Six Sigma for Organizational Excellence; Springer: Berlin/Heidelberg, Germany, 2015; ISBN 9788132223245.

111. Luo, Z. Mechanism Design for Sustainability; Springer: Dordrecht, The Netherlands, 2013; ISBN 9789400759947.

112. Govindan, K.; Azevedo, S.G.; Carvalho, H.; Cruz-Machado, V. Impact of supply chain management practices on sustainability. J. Clean. Prod. 2014, 85, 212-225. [CrossRef]

113. Kandananond, $\mathrm{K}$. The application of water footprint and six-sigma method to reduce the water consumption in an organization. Int. J. GEOMATE 2019, 17, 21-27. [CrossRef]

(C) 2020 by the authors. Licensee MDPI, Basel, Switzerland. This article is an open access article distributed under the terms and conditions of the Creative Commons Attribution (CC BY) license (http://creativecommons.org/licenses/by/4.0/). 